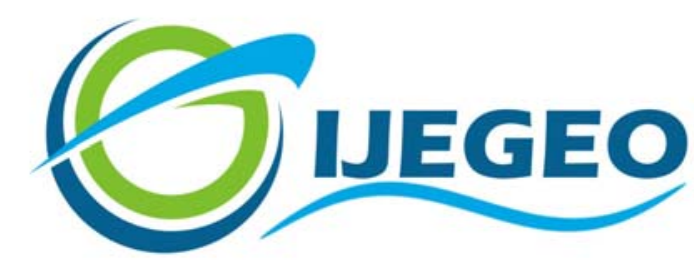

International Journal of Environment and Geoinformatics (IJEGEO) is an international, multidisciplinary, peer reviewed, open access journal.

\title{
Effect of Rainfall Variability on Spring Discharge in the Masingini Catchment, Zanzibar-Tanzania
}

\section{Yussuf I. ABDALLA, Mary MAKOKHA., Mohammed K MAALIM}

\author{
Chief in Editor \\ Prof. Dr. Cem Gazioğlu \\ Co-Editors \\ Prof. Dr. Dursun Zafer Şeker, Prof. Dr. Şinasi Kaya, \\ Prof. Dr. Ayşegül Tanık and Assist. Prof. Dr. Volkan Demir
}

Editorial Committee (March 2021)

\begin{abstract}
Assoc. Prof. Dr. Abdullah Aksu (TR), Assit. Prof. Dr. Uğur Algancı (TR), Prof. Dr. Bedri Alpar (TR), Assoc. Prof. Dr. Aslı Aslan (US), Prof. Dr. Levent Bat (TR), Prof. Dr. Paul Bates (UK), İrşad Bayırhan (TR), Prof. Dr. Bülent Bayram (TR), Prof. Dr. Luis M. Botana (ES), Prof. Dr. Nuray Çağlar (TR), Prof. Dr. Sukanta Dash (IN), Dr. Soofia T. Elias (UK), Prof. Dr. A. Evren Erginal (TR), Assoc. Prof. Dr. Cüneyt Erenoğlu (TR), Dr. Dieter Fritsch (DE), Prof. Dr. Çiğdem Göksel (TR), Prof.Dr. Lena Halounova (CZ), Prof. Dr. Manik Kalubarme (IN), Dr. Hakan Kaya (TR), Assist. Prof. Dr. Serkan Kükrer (TR), Assoc. Prof. Dr. Maged Marghany (MY), Prof. Dr. Michael Meadows (ZA), Prof. Dr. Nebiye Musaoğlu (TR), Prof. Dr. Masafumi Nakagawa (JP), Prof. Dr. Hasan Özdemir (TR), Prof. Dr. Chryssy Potsiou (GR), Prof. Dr. Erol Sarı (TR), Prof. Dr. Maria Paradiso (IT), Prof. Dr. Petros Patias (GR), Prof. Dr. Elif Sertel (TR), Prof. Dr. Nüket Sivri (TR), Prof. Dr. Füsun Balık Şanlı (TR), Prof. Dr. Uğur Şanlı (TR), Duygu Ülker (TR), Prof. Dr. Seyfettin Taş (TR), Assoc. Prof. Dr. Ömer Suat Taşkın (TR), Assist. Prof. Dr. Tuba Ünsal (TR), Dr. Manousos Valyrakis (UK), Dr. İnese Varna (LV), Dr. Petra Visser (NL), Prof. Dr. Selma Ünlü (TR), Assoc. Prof. Dr. Oral Yağcı (TR), Prof. Dr. Murat Yakar (TR), Assoc. Prof. Dr. İ. Noyan Yılmaz (AU); Assit. Prof. Dr. Sibel Zeki (TR)
\end{abstract}

Abstracting and Indexing: TR DIZIN, DOAJ, Index Copernicus, OAJ, Scientific Indexing Services, International Scientific Indexing, Journal Factor, Google Scholar, Ulrich's Periodicals Directory, WorldCat, DRJI, ResearchBib, SOBIAD 


\title{
Research Article
}

\section{Effect of Rainfall Variability on Spring Discharge in the Masingini Catchment, Zanzibar-Tanzania}

\author{
Yussuf I Abdalla ${ }^{1, *}$;D , Mary Makokha ${ }^{1}$, Mohammed K Maalim² iD \\ ${ }^{1}$ School of Pure and Applied Sciences, Department of Geography, Kenyatta University, Nairobi, Kenya. \\ ${ }^{2}$ Institute of Marine Sciences, University of Dar es Salaam, Zanzibar, Tanzania. \\ E-mail: yuthersif2@yahoo.com \\ Correspondence author: Y.I. Abdalla \\ E-mail: yuthersif2@yahoo.com
}

Received: 22 Agu 2020

Accepted: 18 Nov 2020

How to cite: Abdalla, et al., (2021). Effect of Rainfall Variability on Spring Discharge in the Masingini Catchment, Zanzibar

International Journal of Environment and Geoinformatics (IJEGEO), 8(1):039-048. doi: 10.30897/ijegeo.784000

\begin{abstract}
Spring discharge from the Masingini catchment plays a crucial role in the Zanzibar Municipality water supply scheme. However, there has been remarkable attenuation in spring discharge over the years due to a change in rainfall patterns. The study's objective was to assess the effect of rainfall variability on Mtoni and Bububu springs discharge in the Masingini catchment. It analyzed rainfall variability on the Masingini catchment between 1992 and 2018 to assess spring discharge at least ten years before and after the water policy. The monthly rainfall data was collected from Tanzania Meteorological Agency in the Zanzibar office. The spring discharge data was collected from Zanzibar Water Authority and supplemented by field measurements of monthly groundwater levels for wet and dry seasons from fifteen boreholes. The data analysis was carried out using the M-K test. The results revealed a non-significant downward trend in seasonal rainfall over rainfall stations due to the decline of seasonal rainfall over the years. Annual rainfall showed a significant decreasing trend for Kizimbani Agromet station $(\mathrm{p}<0.05)$. On the other hand, the groundwater level dropped by an average of $5 \pm 2.6 \mathrm{~m}$ between the long rainy and dry seasons. The maximum and minimum spring discharges coincide with wet and dry seasons, respectively. There was a significant decreasing trend in annual spring discharge at $\alpha=0.05$ and $\alpha=0.01$ for Mtoni and Bububu spring discharge, respectively. The M-K revealed a significantly positive correlation of annual spring discharge and rainfall, $\tau=0.333$ and $\tau=0.453$ for Mtoni and Bububu spring, respectively, implying that discharge increases as rainfall increases. The average daily discharge of Mtoni and Bububu spring declined by $23.9 \%$ and $18.9 \%$, respectively, before and after water policy. The study concluded that rainfall variability was the primary hydroclimate factor for declining spring discharge on the catchment.
\end{abstract}

Keywords: Bububu Spring, Mann-Kendall Analysis, Mtoni Spring, Rainfed Groundwater Catchment

\section{Introduction}

Springs are playing a crucial role in the Zanzibar Municipality water supply scheme. They have been used for water supply for all purposes since the early 1920s (Haji et al., 2010; FINNIDA, 1992) up to date. Mtoni and Bububu springs are among the utmost potential springs from which water supply for the old Zanzibar Town is originated (Elliott et al., 2012; Ufuzo et al., 2012). These springs are found in a rain-fed catchment of Masingini catchment in the Urban West Region away from Zanzibar Town (Elliott et al., 2012). Mtoni and Bububu springs contribute $10,000 \mathrm{~m}^{3} /$ day $(14 \%$ of the total supply) to the Municipal water supply scheme, and boreholes and water cave (Mato, 2015; ZAWA, 2009) are contributing the remainder. However, a remarkable water decline has been observed from the Masingini catchment's springs over the years due to a change in rainfall patterns and groundwater development (JICA, 2017; Mato, 2015). ZAWA (2009) reported spring discharge declined from 5,327 to $2980 \mathrm{~m}^{3} / \mathrm{d}$ and from 4820 to $3000 \mathrm{~m}^{3} / \mathrm{d}$ for Mtoni and Bububu springs, respectively, as traced from 1993 to 2008 . Besides, the legacy of the springs in water supply planning is shrinking gradually, and this may lead to the potential loss in water supply shortly (ZAWA, 2014; ZAWA, 2009).

To ensure recharge zones of the springs are protected, during the 1990s, the Revolution Government of Zanzibar declared protection of Masingini Forest catchment (RGoZ, 2013). Since the sustainability of the springs is under the sustainability of the watershed, regular monitoring of the springs' lives is a prerequisite for sustainable water supply. Therefore, this study aimed at assessing the effect of rainfall variability on Mtoni and Bububu springs discharge in the Masingini catchment.

The significance of studying rainfall on this catchment relies on the fact that rainfall is the only source of freshwater recharge; hence its variability results in the vulnerability of springs discharge (RGoZ, 2017; Kombo and Kanyama, 2015). Likewise, the groundwater table is vulnerable to rainfall variability, which results in a decrease in spring discharge (Liu et al., 2018; Mato, 2015). It is hypothesized that, by mingling rainfall variability and spring discharge trends on Masingini 
catchment, it is possible to determine the potential of springs in the water supply scheme (Brauer et al., 2016). The trend of rainfall between 1992 and 2018 (27 years) was used because this was the period whereby indications of changes in rainfall variability were experienced in Zanzibar (Watkiss et al., 2012). Besides, the environmental policy of Zanzibar was approved in 1992 after the first Earth Summit toward the adoption of Integrated Water Resources Management in Zanzibar Island (RGoZ, 2013). After that, water policy, water Act of 2006, and Zanzibar Water Authority was approved in 2004 and 2006, respectively, to manage the sector (RGoZ, 2013; JICA, 2008; Gorji et al., 2019). Therefore, this study aimed to assess the spring's discharge at least ten years before and after approving water policy and ZAWA and establishing the future potential of these precious springs in the Zanzibar Municipal water supply.

\section{Materials and Methods}

\section{Description of study area}

Zanzibar Island is one of the Indian Ocean's islands that is located $40 \mathrm{Km}$ away from Tanzania mainland. It lies

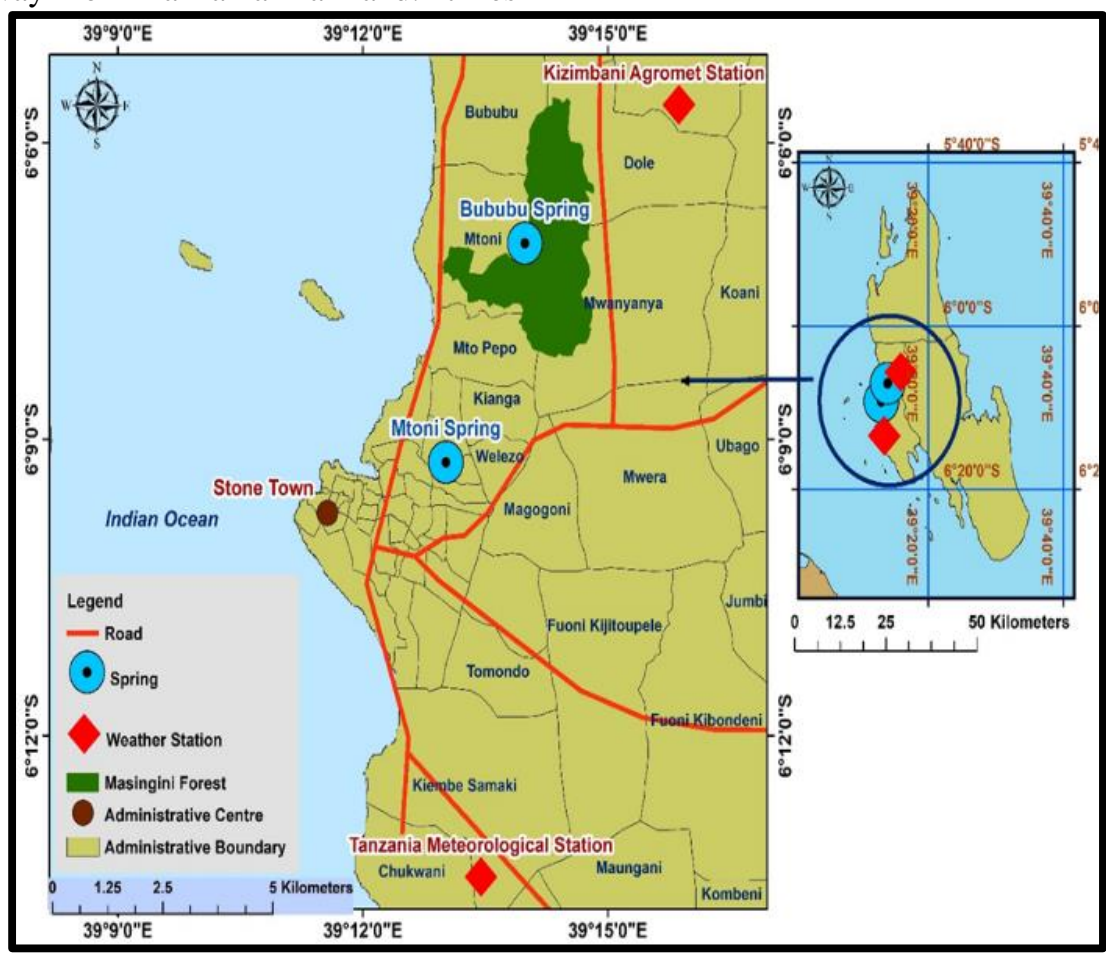

Figure 1: Map showing the Masingini catchment.

\section{Climate conditions}

The most concrete effect of today's climate change manifests itself with the dramatic changes experienced in precipitation regimes (Direk et al., 2012; Simav et al., 2015; Ülker et al., 2018). The island experiences a tropical climate with reliable bimodal rainfall influenced by monsoon winds. The heavy rain is noted from March to May. Another wet season runs from the northeast during November and December, with an average rainfall of $1800 \mathrm{~mm}$ and $1500 \mathrm{~mm}$, respectively. Sikat et al. (2011) reported that a heavy rainy season and the short rainy season form an average of $52 \%$ and $24 \%$ of the total rains, respectively. Meanwhile, Masika and Vuli rains collectively contribute mean recharge of $28 \%$, as higher recharge happens from April to May and between latitude $4^{\circ} 50^{\prime}$ and $6^{\circ} 30^{\prime}$ 'South and longitude $39^{\circ} 10^{\prime}$ and $39^{\circ} 50^{\prime}$ East. Zanzibar Island covers an area of about $1530 \mathrm{~km}^{2}$, and its highest altitude is approximately 120metres above sea level (The World Bank Group, 2016; Mato, 2015). The average population for the Urban West Region is 593,678, and an increase in population from 2002 to 2012 is 203,604 , with an average annual population growth rate of $4.2 \%$. The population density for the Urban West Region is 2581 persons per $\mathrm{Km}^{2}$ (URT, 2013). Figure 1 shows the location of the Masingini catchment in Zanzibar Island in detail. Masingini catchment originates from Masingini reserved forest (566ha) that serves as the primary catchment for Stone Town. It is also home to some wildlife, including endangered species such as Zanzibar red Colobus. The Masingini forest also plays a significant role in groundwater conservation. It is the source of Mtoni and Bububu springs that the Zanzibar Water Authority is officially used for water supply. 
catchment can be classified as Miocene $\mathrm{M}_{3}$ rocks (Sandy clays, marls, and clayey sands), which are part of the ancient Miocene Rufiji/Ruvu delta. These rocks are bluish-grey to bluish-green, dense, roughly sorted chalky, frequent gravel stringers that weathered to a red, yellow, or brown color (Sikat et al., 2011; Hardy et al., 2015). The Masingini ridge is characterized by deep soil rich in nutrients that support a variety of crops, including coconuts, mangoes, home gardens, herbs, and others (Masore, 2011).

\section{Hydrology and Drainage}

The study area is falling under the Masingini and Donge ridges, whereby most of the perennial stream systems (surface and subsurface streams) are originated in Zanzibar Island. Topographic (gradient) features of the catchment and island support stream systems to drain westerly on the watershed. Subsurface flow has a predominant basin due to sinkholes and karstic formation that influence the disappearance of the major surface streams. These soil characteristics tend to have a high reaction to heavy rainfall such that infiltration becomes very rapid, combined with the fast-rising in the groundwater table. Masingini ridge is the fundamental part of water supply for Zanzibar town by creating immense groundwater reserves. The catchment is composed of Quaternary $\left(\mathrm{Q}_{1}\right)$; and least productive aquifer (Miocene $\mathrm{M}_{3}$ ), though groundwater extraction (by wells or boreholes) is associated with useful yields from laterites, sand bands, and limestone lenses. Miocene aquifers $\left(\mathrm{M}_{3}\right)$ are the aquifers with hydrogeological significance as their bases originate from corridor zones (Valleys) lies between ridges. The outcrops of the catchment possess about $7 \%$ unconfined storage value, and the water table may rise to an average of $7.91 \mathrm{~m}$ per year. It also discharges through the perennial stream system (springs) that flow from the slopes of the Masingini Ridges (UNDP, 1987; Halcrow, 1994).

\section{Data Collection and analysis Data collection}

The monthly rainfall data was collected as historical data between 1992 and 2018. This data was collected from the Tanzania Meteorological Agency at the Zanzibar office; for TMA (airport) rainfall station and Kizimbani Agromet Station, as mapped in Figure 1. The mass curve analysis was used for data quality analysis for each station. The 27 years cumulative rainfall amount was plotted against time (year) to find the need for data corrections. On the other hand, the daily spring discharge time series of Mtoni and Bububu springs data from 1992 to 2018 was collected from the Zanzibar Water Authority. The data was arranged based on the wet and dry seasons to establish a significant trend between the two seasons and establish spring discharge dependency on rainfall. The spring discharge is estimated using the formula 1 as shown below, where $Q$ is the spring discharge, $H$ is head in feet, and $L$ is the length in feet.

$Q=1.25 H^{1.49}(L+2 H)-0.11$
The equation means that water from the spring flow to the gauge chamber of weir length $L\left(L=36^{\prime}\right)$ while water head $(H)$ is measured by water gauge daily. The recorded water head is input to the formula 1 , and the result $(Q)$ is spring discharge in gallon per hour, often the discharge is converted into cubic meter per day.

\section{Data Analysis}

\section{The Mann-Kendall test}

The rainfall time series data and historical spring discharge data were analyzed by using the M-K test. The $\mathrm{M}-\mathrm{K}$ test was applied to detect any statistical significance trends under the null hypothesis $\left(H_{0}\right)$ "there is no monotonic trend in the series" and alternate hypothesis $(\mathrm{Ha})$ "there is a monotonic trend in a series." This was to establish significant trends in monthly, seasonal, and annual rainfall and spring discharge data series at $5 \%$ and $1 \%$ significance levels. The MannKendall test statistic ( $Z$ ) was carried out, as shown in equations 2, 3, 4, and 5 as follows:

$s=\sum_{k=1}^{n-1} \sum_{j=k+1}^{n} \operatorname{sgn}\left(x_{j}-x_{k}\right)$

Where $x_{\mathrm{j}}$ and $x_{\mathrm{k}}$ are the time series observation, $n$ is the length of time series, and sgn ( $\mathrm{x})$ is defined by function expressed in equation 3.3.

$\operatorname{sgn}(x)=\left\{\begin{array}{c}1 \text { if } x>0 \\ 0 \text { if } x=0 \\ -1 \text { if } x<0\end{array}\right.$

$\operatorname{VAR}(S)=\frac{1}{18}\left[n(n-1)(2 n+5)-\sum_{p=1}^{q} t_{p}\left(t_{p}-\right.\right.$ 1) $\left.\left(2 t_{p}+5\right)\right]$

Where $t_{p}$ is the number of ties at $p^{\text {th }}$ value, and $q$ is the number of tied groups. The variance (VAR) and $\mathrm{S}$ are used to estimate the value of standardized test statistics $(\mathrm{Z})$, as shown in equation 5 .

$Z=\left\{\begin{array}{l}\frac{S-1}{\sqrt{V A R(S)}} \text { if } S>0 \\ 0 \text { if } S=0 \\ \frac{S+1}{\sqrt{V A R(S)}} \text { if } S<0\end{array}\right.$

The values of $\mathrm{Z}$ are used to indicate the presence of statistical significance in the hydrologic time series. The $\mathrm{Z}$ positive and negative values indicate an upward trend and downward trends in the data time series. When $|Z|$ $>Z_{1-\alpha / 2}$, the null hypothesis $\left(H_{0}\right)$ was rejected as a statistically significant trend is exiting in the data time series at the respective significance values of $\propto=0.05$ and 0.01 .

\section{Results and Discussion Rainfall Variability}

The temporary and spatial distribution of rainfall over the catchment was investigated from TMA and Kizimbani Agromet stations, as represented in Figure 2. The monthly rainfall analysis was denoted to be a bimodal rainfall regime. As such, heavy rains season 
runs from March to May and short rains season occurs from October to December. The two rain seasons were separated by dry months that run from June to September. The results are in agreement with the Hamisi's (2013) findings in Tanzania during the study of rainfall trends and variability over Tanzania, where he found that coastal areas of Tanzania experience a bimodal rainfall regime.

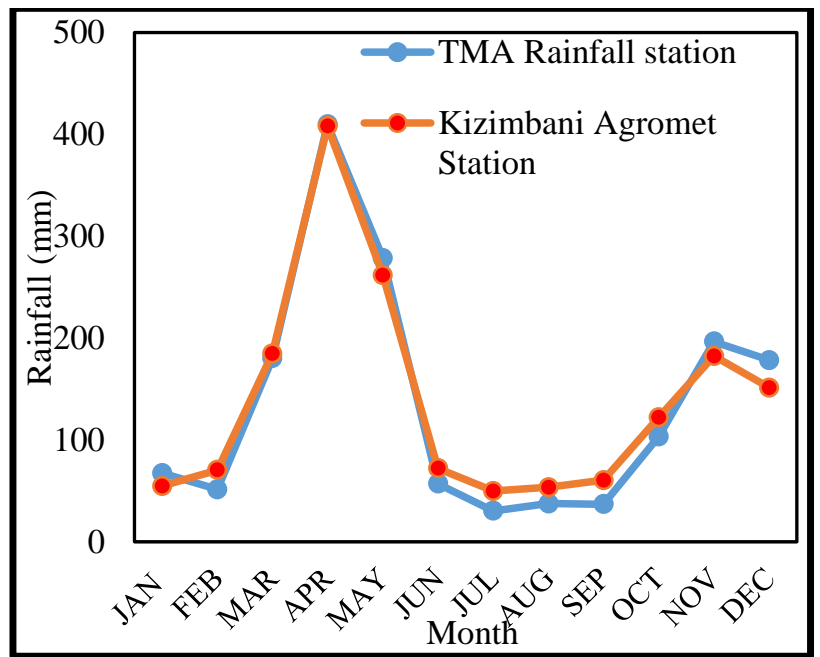

Figure 2: Mean monthly rainfall from 1992 to 2018

Monthly, Seasonally, and Annual rainfall trend analysis

The trend in rainfall data for each month was established separately using the M-K test, as shown in Figure 3 and Table 1. The TMA rainfall station analysis revealed statistically non-significant trends in monthly data of twenty-seven (27) years as both upward and downward trends were denoted. April, September, and November showed positive values of the $\mathrm{M}-\mathrm{K}$ correlation coefficient; meanwhile, the remaining months showed decreasing trends. On the other hand, the Kizimbani Agromet station analysis showed a statistically nonsignificant increasing trend in August, September, and November due to the positive values of $\mathrm{M}-\mathrm{K}$ coefficients. Meanwhile, the remaining months showed statistically non-significant decreasing trends due to negative values of $\mathrm{M}-\mathrm{K}$ coefficients at $p=0.05$.

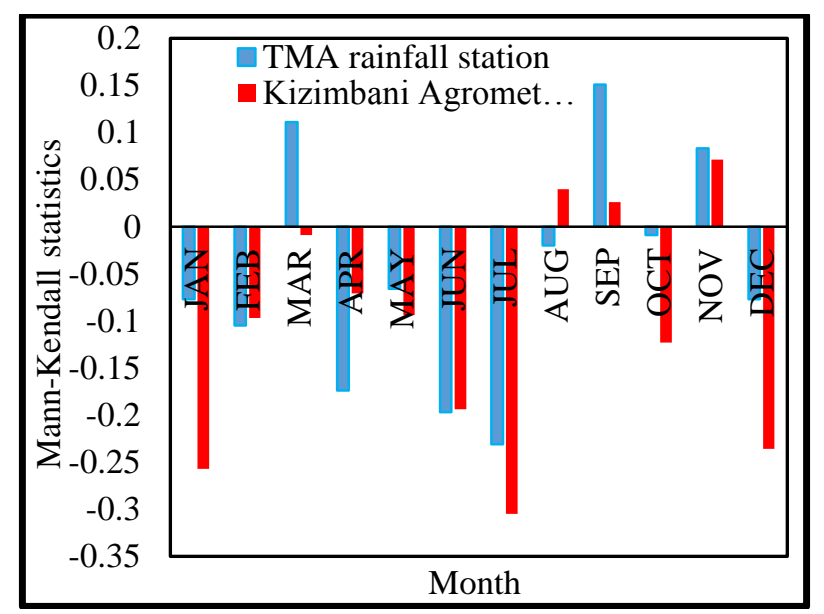

Figure 3: M-K statistics for monthly trend (1992-2018).

Table 1: Summary statistical analysis of rainfall data along with the M-K test at TMA and Kizimbani Agromet stations

\begin{tabular}{|c|c|c|}
\hline \multirow[t]{2}{*}{ Time series } & \multicolumn{2}{|c|}{ M-K test (Z) } \\
\hline & TAM rainfall station & Kizimbani Agromet station \\
\hline JAN & -0.077 & -0.257 \\
\hline FEB & -0.105 & -0.097 \\
\hline MAR & 0.111 & -0.009 \\
\hline APR & -0.174 & -0.071 \\
\hline MAY & -0.666 & -0.094 \\
\hline JUN & -0.197 & -0.194 \\
\hline JUL & -0.231 & $-0.305^{*}$ \\
\hline AUG & -0.02 & 0.040 \\
\hline SEP & 0.151 & 0.026 \\
\hline OCT & -0.009 & -0.123 \\
\hline NOV & 0.083 & 0.071 \\
\hline DEC & -0.077 & -0.236 \\
\hline MAM & -0.071 & -0.100 \\
\hline JJAS & -0.157 & -0.219 \\
\hline OND & -0.048 & -0.128 \\
\hline Annual & -0.111 & $-0.271 *$ \\
\hline
\end{tabular}

(- indicates decreasing (downward trend) and $*$ indicates significant at $\alpha=0.05)$ 
Figure 4 shows seasonal variation in rainfall for the long rainy season (MAM) from 1992 to 2018. All two rainfall stations have been characterized by a statistically nonsignificant downward trend with abrupt rise and fall of rainfall amount over twenty-seven years. The decreasing trend was due to the negative values of the M-K test (Zstatistics).

The statistically non-significant trends were due to greater values of $p$ at a 95\% significance level. The highest rainfall amount for the season MAM was denoted in 2017 with a value of $419 \mathrm{~mm}$ at TMA and $508.6 \mathrm{~mm}$ at Kizimbani Agromet station, which was resulted from heavy rains season being far above normal (Revolutionary Government of Zanzibar, 2017). The lowest ever recorded season rainfall (MAM) was denoted in 2003, which was attributed to a prolonged drought of 2003 in Zanzibar Island (Watkiss et al., 2012).

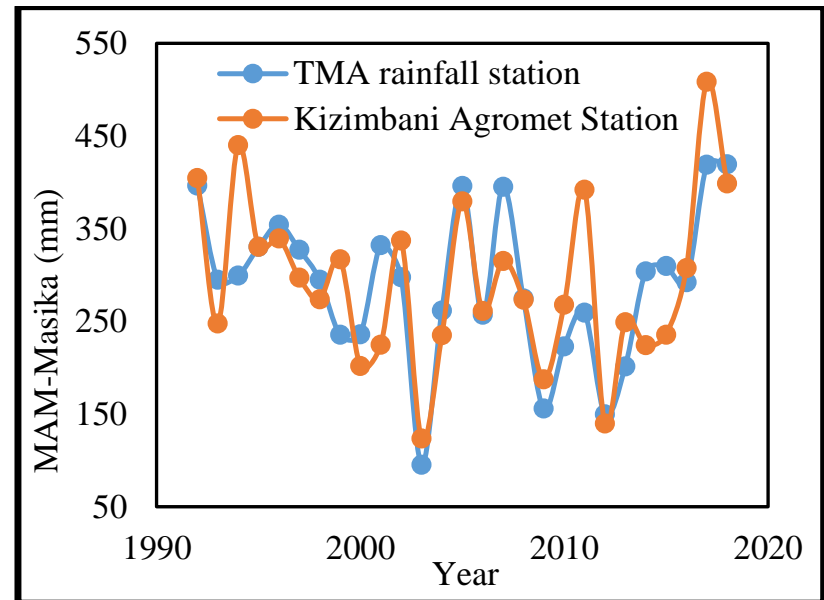

Figure 4: Seasonal variation in rainfall for the long rainy season (1992-2018)

Figure 5 shows seasonal variation in rainfall for dry season JJAS over the TMA and Kizimbani Agromet stations over twenty-seven years. The analysis showed a statistically non-significant decreasing trend $(p=0.05)$ over two rainfall stations, attributed to a decrease in rainfall amount in dry months. This resulted from decreasing in the number of rainy days in dry months over the years. The findings also showed that the TMA and Kizimbani Agromet stations receive an average rainfall of $40.65 \pm 18.12 \mathrm{~mm}$ and $60.33 \pm 27.15 \mathrm{~mm}$, respectively, meaning the catchment receives rainfall even during dry months. The findings are in agreement with the Kabanda (2018) and JICA (2017) findings, which revealed that no month is entirely devoid of rainfall in the coastal areas; and Zanzibar Island receives rainfall at least five days per month attributed to the change of monsoon and movement of tropical convergence zone.

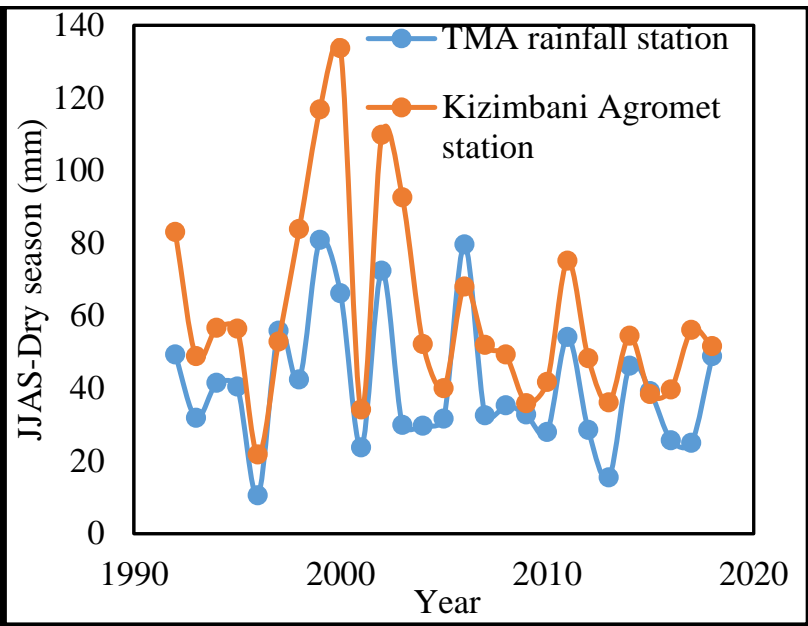

Figure 5: Seasonal variation in rainfall for dry season (1992-2018).

Figure 6 depicts the seasonal variation in rainfall for the short rainy season (OND) from TMA and Kizimbani Agromet stations over twenty-seven years. All two rainfall stations were recorded the highest rainfall amount in 1997 with a value of $416 \mathrm{~mm}$ at TMA and $351.5 \mathrm{~mm}$ at Kizimbani Agromet station, which was attributed to El Niño of 1997-1998 (Kabanda, 2018). The lowest rainfall amount for the OND season was recorded in 2001 with a value of $34.9 \mathrm{~mm}$ at TMA and $71.6 \mathrm{~mm}$ at Kizimbani Agromet station, attributed to the poor performance of the short rains season of 2001/2002. The findings also revealed a statistically non-significant decreasing trend at all rainfall stations due to greater values of $p$ at a $95 \%$ significance level. The decreasing trend could be attributed to a decrease in the number of rainy days in short rains months associated with changes of natural cyclic patterns of monthly rainfall due to climate change (Watkiss et al., 2012).

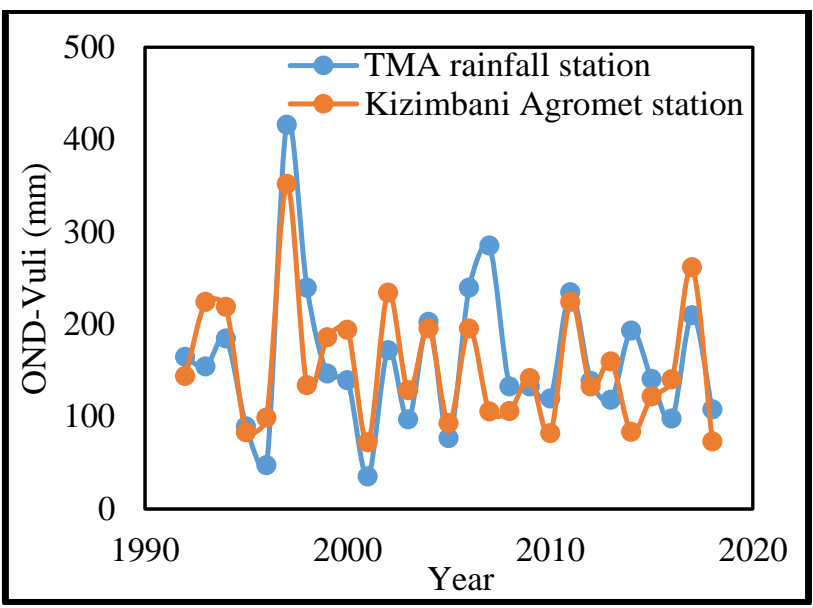

Figure 6: Seasonal variation in rainfall for the short rainy season (1992-2018) 
Figure 7 shows the annual rainfall trend for TMA and Kizimbani Agromet stations. All two rainfall stations have been characterized by decreasing annual rainfall trends with frequent abrupt rise and fall of annual rainfall over the twenty-seven years. For TMA station, the highest annual rainfall was $2459.76 \mathrm{~mm}$ observed in 1997, while the lowest annual rainfall was denoted in 2003 with a value of $704.04 \mathrm{~mm}$. The highest and lowest annual rainfall recorded was attributed to hefty rains associated with El Niño season in 1997/1998 and prolonged dry seasons in 2003-2004, respectively (Watkiss et al., 2012).

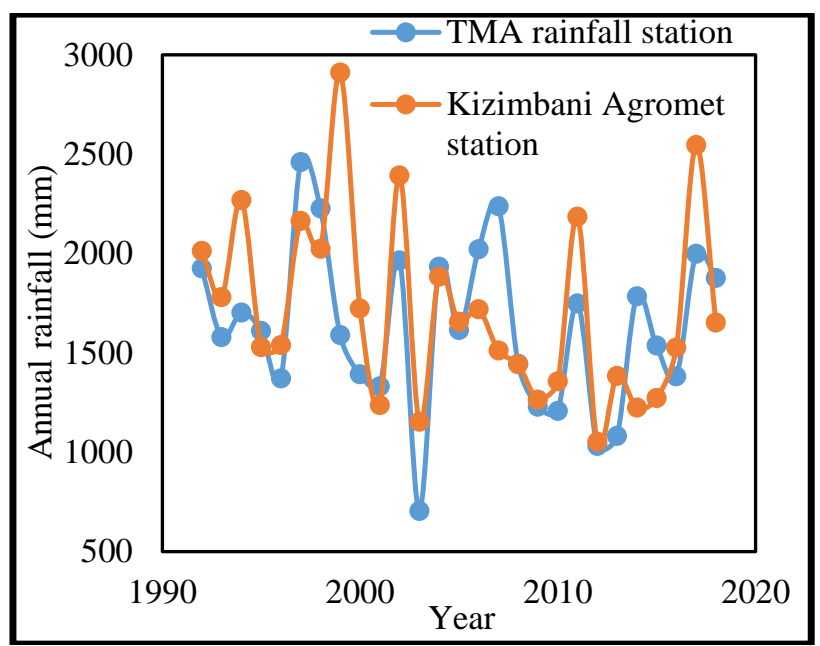

Figure 7: Annual variation in rainfall (1992-2018)

On the other hand of Kizimbani Agromet station, the highest and lowest annual rainfall values were $2909.52 \mathrm{~mm}$ and $1051.56 \mathrm{~mm}$, respectively, as observed in 1999 and 2012. The higher rainfall amount was attributed to the satisfactory performance of all three rainfall seasons in 1991; meanwhile, the El Niño of 2012 was the factor that attributed to low annual rainfall in 2012.

Besides, the findings suggested that the Kizimbani Agromet station receives a relatively higher annual rainfall compared to the TMA rainfall station. These findings are in agreement with the Haji et al. (2010) results in Zanzibar Island, who found that Northwest parts of Zanzibar Island (including Kizimbani areas) receive relatively higher annual rainfall distribution due to fairly high distribution of seasonal rainfall. The M-K test revealed a decreasing trend in annual rainfall series that was statistically significant for Kizimbani Agromet station $\quad(\tau=-0.048, p($ two - tailed $)<0.05)$. In contrast, the decreasing trend was not statistically significant for TMA station $(\tau=-0.111, p$ (two tailed) $>0.05$ ). This indicates that annual rainfall over the catchment is continuously declining over the years. It could be attributed to prolonged dry seasons and a decrease in rainfall amount in wet seasons, respectively (Kabanda, 2018; Watkiss et al., 2012).

Furthermore, the results highlighted that seasonal variations in rainfall over the catchment affect both spring discharge and boreholes water levels. Recently studies by Sikat et al. (2011) and Haji et al. (2010) suggested that groundwater recharge on the Zanzibar Island is regarded as the condition of rainfall, such that the maximum recharge takes place during the heavy rainy season (MAM), followed by the short rainy season (OND), and the dry seasons. Besides, the results showed that spring discharge is the condition of the seasonal rainfall over the catchment, as it was observed to fluctuate significantly with seasonal variation in rainfall over the years. All springs showed the largest discharge rise during the heavy rainy season, the short rainy season, and dry season (in decreasing order). On the other hand, the results indicated that the boreholes water level fluctuated by $5 \pm 2.6 \mathrm{~m}$ between the heavy rains and dry seasons. These findings are in agreement with the results reported by FINNIDA (1992), which revealed that water table fluctuations range between $5-7 \mathrm{~m}$, which occurs during the rainy seasons, and some take place during dry seasons.

\section{The trend in spring discharge}

Monthly spring discharge analysis revealed two peaks attributed to variations in monthly rainfall over the year, as seen in Figure 8. The highest peak coincides with the long rainy season MAM and the lowest peak corresponding with the short rainy season OND. For Mtoni spring, the lowest and highest discharge values were observed in March and May, respectively. Meanwhile, for Bububu spring, the lowest and highest discharges were denoted in February and June, respectively. The low spring discharge in February and March could be attributed to the fall of the water table in the aquifers resulted from groundwater abstraction and a decrease in recharge to aquifers due to the low number of rainy days. Meanwhile, high spring discharge in May and June was attributed to the long rainy season MAM that was associated with high recharge over the catchment (Makame and Kangalawe, 2018; JICA, 2017; Kombo and Kanyama, 2015; Sikat et al., 2011).

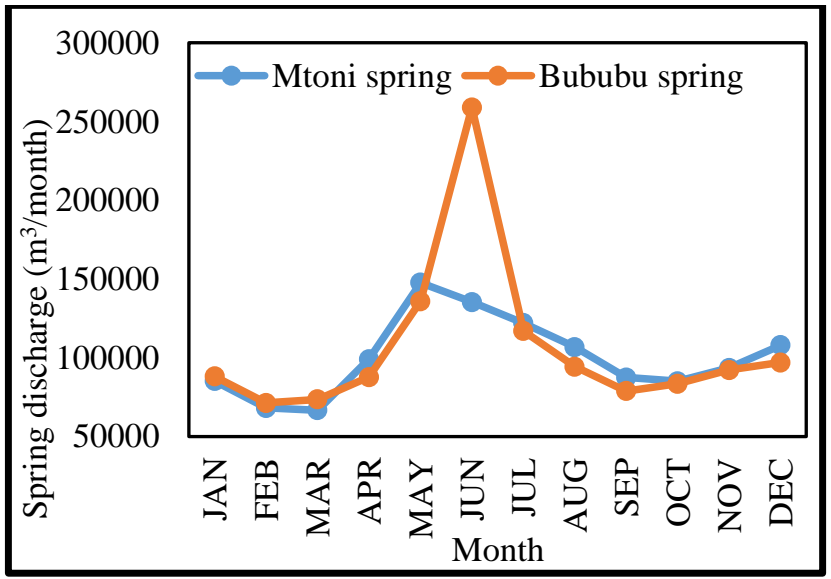

Figure 8: Mean monthly spring discharge for Mtoni and Bububu springs

Besides, Bububu spring is characterized by high flow over the year compared to Mtoni spring because it is surrounded by elevated forest and thick bush areas that increase the water retention capacity of intake area and recharge to spring source (Meuli and Wehrle, 2001). However, hydrogeological both springs originate from 
the same aquifers of marl, sand clay, and clayey sand of Miocene. But topography and vegetation cover around Bububu spring create a thick cover that stores and releases groundwater to the spring. Human activities and housing development surrounding Mtoni spring associated with encroachment and increasing groundwater abstraction through private wells that threaten the sustainability of Mtoni spring (Mato, 2015; Ufuzo et al., 2012).

The results also showed that the springs discharge throughout the year due to reliable rainfall, high infiltration capacity of the soil, and sufficient aquifer retention capacity which provide a favorable environment for plenty of recharge during the wet seasons which enable discharge to sustain throughout dry months (Van Sickle, 2016). The month trend analysis showed that all springs were dominated by upward trends, as some trends were statistically significant at their respective significance level. Table 2 shows a statistical summary of trends and variations in monthly, seasonally, and annual spring discharge along with the M-K test.

Table 2: Statistical summary of Mtoni and Bububu springs discharge along with the M-K test.

\begin{tabular}{|c|c|c|}
\hline \multirow[t]{2}{*}{ Time series } & \multicolumn{2}{|c|}{ M-K trend (Z) } \\
\hline & Mtoni spring & Bububu spring \\
\hline JAN & 0.333 & 0.156 \\
\hline FEB & 0.244 & -0.156 \\
\hline MAR & 0.244 & 0.022 \\
\hline APR & $0.600 *$ & $0.539 *$ \\
\hline MAY & $0.689 * *$ & $0.778 * *$ \\
\hline JUN & $.0778 * *$ & 0.333 \\
\hline JUL & $0.822 * *$ & $0.600 *$ \\
\hline AUG & $0.867 * *$ & $0.600 *$ \\
\hline SEP & $0.822 * *$ & $0.511^{*}$ \\
\hline OCT & $0.644 * *$ & 0.378 \\
\hline NOV & $0.733 * *$ & 0.422 \\
\hline DEC & $0.556^{*}$ & 0.333 \\
\hline МАМ & $0.689 * *$ & $0.644 * *$ \\
\hline JJAS & $0.911 * *$ & 0.467 \\
\hline OND & $0.733 * *$ & $0.556^{*}$ \\
\hline Annual & $-0.299 *$ & $-0.442 * *$ \\
\hline
\end{tabular}

(*) indicates significance at $\alpha=0.05$ and (**) indicates significance at $\alpha=0.01$

\section{Seasonal and Annual trend in spring discharge}

For the long rainy season MAM, the results showed a statistically significant increasing trend with $\tau=$ $0.689, p$ (two - tailed $)<0.01$ and $\tau=0.644, p$ (two tailed $)<0.01$ for Mtoni and Bububu springs, respectively. This indicates that spring discharge increases significantly as rainfall increases in the long rainy season. The discharge trend could be regarded as a condition of seasonal rainfall because it increases during the wet seasons. During the rainy season, infiltration increases to recharge the aquifer and cause the water level to rise. As such, excess water is allowed to discharge naturally through springs (Fetter, 2001). It was also noted that the peak discharge of Mtoni spring occurs within MAM attributed to the direct infiltration of rainwater from immediate areas (Meuli and Wehrle, 2001).

For the dry season JJAS, the findings revealed both springs experience low discharge quantity in the dry season compared to the long and short rainy seasons. During the dry season, infiltration decreases, and the catchment water level decreases due to groundwater pumping and hence causing spring discharge attenuation. The findings also showed an upward trend that was statistically significant for Mtoni spring, $\tau=$ $0.911, p($ two - tailed $)<0.01$, and statistically nonsignificant for Bububu spring, $\tau=0.467$, $p$ (two tailed) $>0.05$. This indicates that Bububu spring discharge does not associate with shallow flow system because its seasonal variation in discharge correlated insignificantly with rainfall patterns of dry season JJAS (Ufuzo et al., 2012). It was also revealed that the peak discharge of Bububu spring occurs in June at the late of MAM and the first month of JJAS. This could be attributed to a lack of direct infiltration of rainwater from the immediate surroundings that cause the peak discharge to occur a few weeks after heavy rains (Meuli and Wehrle, 2001).

For the short rainy season OND, the M-K test revealed a statistically significant upward trend, $\tau=0.733$, $p$ (two tailed $)<0.01$, and $\tau=0.556, p($ two - tailed $)<0.05$ for Mtoni and Bububu springs, respectively. This means spring discharge increases significantly as short rainy season increases. Geologically, during the short rainy season OND, the surplus water is available to recharge aquifers to rise water levels as well as to increase spring discharge on the catchment. Figure 9 shows trends and variations in annual spring discharge over the Masingini catchment over twenty-seven (1992-2018). The M-K test 
revealed a statistically significant downward trend, $\tau=$ $-0.299, p($ two - tailed $)<0.05$ at Mtoni spring, and $\tau$ $=-0.442, p($ two - tailed $)<0.01$ at Bububu spring, meaning the spring discharge declines over the year. The results are in agreement with Ufuzo et al. (2012) findings, which revealed a significant decreasing trend in annual discharge over Mtoni and Bububu springs due to a decrease in yearly rainfall resulted from a decline in annual-monthly rain over the catchment. They added that the decline in spring discharge was also attributed to an increase in groundwater abstraction resulted from population growth and socio-economic development surround the spring intakes over the catchment.

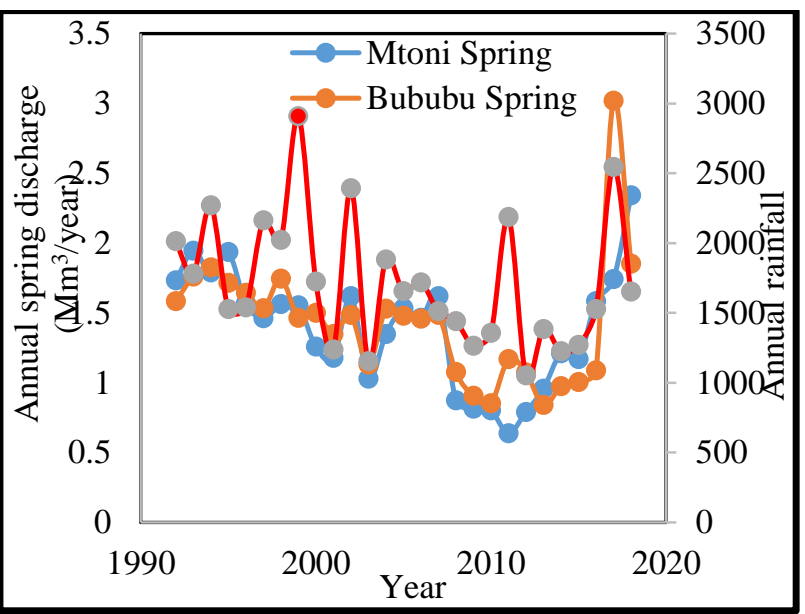

Figure 9: Annual spring discharge and annual rainfall (1992-2018)

\section{Spring discharge before and after Water Policy}

The study analyzed spring discharge variation ten years before and after water policy to study the policy's effect on spring discharge management. The results showed that the average daily spring discharge decreased by $23.9 \%$ and $18.9 \%$ for Mtoni and Bububu springs discharge, respectively, meaning discharge attenuates continuously over time. This could be attributed to the extended effects of climate change that impact cyclic patterns of annual rainfall and change of groundwater use patterns resulted from population growth and socioeconomic development (Mato, 2015; Ufuzo et al., 2012; Shah, 2003). The National Water Policy 2004 recognizes that the limited water reserve is only nourished by rainfall. The survival of reserves depends upon balancing the rate of extraction for human use and the rainfall recharge. Thus, it established a system of water rights and groundwater abstraction control in practice to ensure the granted permits for groundwater exploitation do not cause detrimental effects on spring discharge. It has also set the guidelines and principles to guide community participation in spring management, monitor recharge and human activities in the catchment, and ensure that spring intake area is protected from ongoing human activities within a watershed.

However, the findings showed that the policy failed to comprehensively manage spring discharge because average annual rainfall before and after the policy was 1893.2 and $1548.5 \mathrm{~mm} /$ annual. JICA (2008) indicated that catchment groundwater development potential was estimated using the mean annual of $1100 \mathrm{~mm}$. Although there was a decreasing trend in annual rainfall (19922018), the catchment receives rainfall greater than average annual rainfall designed for a safe yield of groundwater extraction from boreholes.

On the other hand, a decline in spring discharge resulted from groundwater users' mismanagement due to unmet water demand pressurized by population growth, rapid urban expansion, and degradation of watersheds. Shah (2003), the water production capability has been worsening with time; the water demand for Zanzibar Municipality was projected to increase from $30,000 \mathrm{~m}^{3} /$ day in 1995 to $90,000 \mathrm{~m}^{3} /$ day in 2015 . Conversely, by 2003 the deficit was $32 \%$ of the total average production for Municipal water demand estimated in 1995. Again, about $61.7 \%$ of the estimated annual water demand for Zanzibar Island sourced from private sources by individuals in 2018. These indicate that as the public water authority fails to meet required water demands, the likelihood of individuals to misuse groundwater exploitation is increasing due to a lack of enforcement of groundwater extraction rights at the local level. As a result, the groundwater level continues to decline, and seawater intrusion deteriorates freshwater supply increasingly in Zanzibar Municipality (Smith et al., 2016; Mato, 2015).

\section{Response of spring discharge with regard to rainfall variability}

The M-K correlation analysis was applied to determine the relationship between seasonal rainfall and spring discharge, annual rainfall, and spring discharge (19922018). For the long rainy season (MAM), spring discharge and rainfall amount were statistically significant correlated, $\tau=0.556, p$ (two tailed) $<0.05$ for Mtoni spring and $\tau=0.511, p($ two - tailed $)<$ 0.05 for Bububu spring. The values of the $\mathrm{R}^{2}$ were 0.309 and 0.261 for Mtoni and Bububu spring, respectively. The coefficient of determination $\left(\mathrm{R}^{2}\right)$ suggests that long rainy season contributes $30.9 \%$ and $26.1 \%$ of the variation in spring discharge for Mtoni and Bububu spring, respectively. The remaining seasons, dry and short rainy seasons, spring discharge and rainfall amount, showed statistically non-significant correlation.

Moreover, the M-K correlation analysis revealed a statistically significant upward relationship between annual spring discharge and annual rainfall amount over the catchment. As such, $\tau=0.333, p($ two - tailed $)<$ 0.05 for Mtoni spring, and $\tau=0.453, p$ (two tailed $)<0.01$ for Bububu spring. The coefficient of determination $\left(\mathrm{R}^{2}\right)$ was 0.111 and 0.205 for Mtoni and Bububu springs, respectively. This means that $11.1 \%$ and $20.5 \%$ of the annual spring discharge variations can be accounted for by annual rainfall for Mtoni and Bububu spring discharge, respectively. Conversely, $\mathrm{R}^{2}$ explains that about $88.9 \%$ and $79.5 \%$ of variations in discharge from Mtoni spring and Bububu spring, respectively, remained unexplained. Therefore, it should be noted that apart from the monthly, seasonal, and annual rainfall amount received on the catchment, the contribution of other factors in spring discharge 
fluctuations cannot be underestimated (Jia et al., 2017; Chinnasamy and Prathapar, 2016; Weissinger et al., 2016).

\section{Acknowledgment}

The authors wish to express their deep sense of appreciation to the Zanzibar Water Authority (ZAWA) and Tanzania Meteorological Agency (TMA) at Zanzibar office for their invaluable support during data collection.

\section{References}

Brdjanovic, D., Meijer, S. C., Lopez-Vazquez, C. M., Hooijmans, C. M., van Loosdrecht, M. C. (Eds.). (2015). Applications of activated sludge models. Iwa Publishing.

Brauer, C. C., Overeem, A., Liejnse, H., Uijlenhoet, R. (2016). The Effect of Differences between Rainfall Measurement techniques on Groundwater and Discharge Simulations in a Lowland Catchment. Hydrological Processes, 30, 3885-2900. doi:10.1002/hyp.10898

Chinnasamy, P., and Prathapar, S. A. (2016). Methods to Investigate the Hydrology of the Himalayan Springs: A Review. IWMI Working Paper 169, 28. doi: $10.5337 / 2016.205$.

Direk, Ş., Şeker, DZ., Musaoğlu, N., Gazioğlu, C. (2012). Monitoring and Management of Coastal Zones Which are Under Flooding Risk with Remote Sensing and GIS, AGU, Fall Meeting 2012. 1596.

Elliott, B., Maalim, M. K., Peeks, H. (2012). Water Quality and Provider Service Efficiency: Stone Town Zanzibar. Unpublished Master thesis: SIT Zanzibar, Tanzania: Coastal Ecology and Natural Resource Management.

Fetter, C. W. (2001). Applied Hydrogeology (4th ed.). Upper Saddle River, New Jersey 07458: PrenticeHall, Inc.

FINNIDA. (1992). Mid-term Review of the Zanzibar Urban Water Supply Development Project. The Hague, The Netherland: International Water and Sanitation Centre.

Gorji, T.; Yıldırım, A.; Sertel, E.; Tanık, A. (2019). Remote sensing approaches and mapping methods for monitoring soil salinity under different climate regimes. International Journal of Environment and Geoinformatics, 6(1), 33-49, doi: 10. 30897 /ijegeo.500452.

Haji, H. S. (2010). Water Balance Assessment in Unguja Island, Zanzibar, Tanzania. Unpublished Master Thesis: The International Institute for Geoinformation Science and Earth Observation.

Halcrow. (1994). The Development of Water Resources in Zanzibar: Final Report. Zanzibar, Tanzania: Revolutionary Government of Zanzibar.

Hamisi, J. (2013). Study of Rainfall Trends and Variability over Tanzania. Nairobi, Kenya: Unpublished research project: University of Nairobi.

Hardy, A., Mageni, Z., Dongus, S., Killeen, G., Macklin, M. G., Majambare, S., Thomas, C. (2015). Mapping hotspots of malaria transmission from pre-existing hydrology, geology and geomorphology data in the pre-elimination context of Zanzibar, United Republic of Tanzania. Parasites and Vectors, 1-15. doi:10.1186/s13071-015-0652-5

Jia, Z., Zang, H., Zheng, X., Xu, Y. (2017). Climate Change and Its Influence on the Karst Groundwater Recharge in the Jinci Spring Region, Northern China. Water, 9(267), 1-15. doi:10.3390/w9040267

JICA. (2008). Implementation Review Study Report on the Project for Zanzibar Urban Water Supply Development Phase II in the United Republic of Tanzania. Zanzibar: Japan International Cooperation Agency.

JICA. (2017). Implementation Review Study Report on The Project for Zanzibar Urban Water Supply Development Phase II in The United Republic of Tanzania. Zanzibar: The Revolution Government of Zanzibar.

Kombo, A. K., Kanyama, A. (2015). Effect of Climate Change and Variability on Water Supply in Zanzibar. International Journal of Marine, Atmospheric and Earth Sciences, 3(1), 1-16.

Liu, X., Hu, L., and Sun, K. (2018). Analysis of Spring Flow Change in the Jinan City Under Influences of Recent Human Activities. PIAHS, 263-268. doi:org/10.5194/piahs-379-263-2018

Makame, O. M., Kangalawe, R. Y. (2018). Water Security and Local People Sensitivity to Climate Variability and Change Among Coastal Communities in Zanzibar. Journal of Sustainable Development, 11(3), 23-32. doi:10.5539/jsd.v11n3p23

Masore, F. M. (2011). Analysis of Land Use Conflict in Zanzibar: A Participatory Approach. Enschede, The Netherlands: Unpublished Thesis.

Mato, R. A. (2015). Groundwater Quality Degradation due to Salt Water Intrusion in Zanzibar Municipality. African Journal of Environmental Science and Technology, 9(9), 734-740. doi:10.5897/AJEST2015.1931

Meuli, C., Wehrle, K. (2001). Spring Catchment (Vol. 4). Switzerland: SKAT, Swiss Centre for Development Cooperation in Technology and Management.

Prendergast, M. E., Rouby, H., Punnwong, P., Marchant, R., Crowther, A., Kourampas, N., Boivin, N. L. (2016). Continental Island Formation and the Archaeology of Defaunation on Zanzibar, Eastern Africa. PLoS ONE, 11(2), 1-23. doi:10.1371/journal.pone.0149565

Revolutionary Government of Zanzibar. (2004). National Water Policy. Zanzibar: Revolutionary Government of Zanzibar.

Revolutionary Government of Zanzibar. (2017). Zanzibar Food Security and Nutrition Analysis Report. Zanzibar, Tanzania: The Department of Food Security and Nutrition of the Ministry of Agriculture, Natural Resources, Livestock and Fisheries Zanzibar.

RGoZ. (2017). Zanzibar Strategy for Growth and Reduction of Poverty III (MKUZA III). Zanzibar: The Revolution Government of Zanzibar.

RGoZ. (2013). Zanzibar Environmental Policy. Zanzibar: The Revolutionary Government of Zanzibar. 
Scholz, W. (2008). Challenges of Informal Urbanization: The Case of Zanzibar/Tanzania. Dortmund: Spring Research Series: PhD Dissertation, Technische Universität Dortmund.

Shah, A. S. (2003). Value of improvements in Water Supply Reliability in Zanzibar Town. Unpublished Masters Report: Yale University, School of Forestry and Environmental Studies.

Sikat, L. B., Becht, R., Vekerdy, Z. (2011). Assessing the Spatial and Temporal Characteristics of Groundwater Recharge in Zanzibar: Toward the Optimal Management of the Groundwater Resources. Enshede, The Netherlands: Published Master thesis: Faculty of Geo-Information Science and Earth Observation of the University of Twente.

Simav, Ö., Şeker, D.Z., Tanık, A. Gazioğlu, C. (2015). Determining the endangered fields of Turkish coasts with coastal vulnerability index. Journal of Map, 153: $1-8$.

Smith, M., Cross, K., Paden, M., and Laban, P. (2016). Spring - Managing groundwater sustainably. Gland, Switzerland: International Union for Conservation of Nature and Natural Resources.

The World Bank Group. (2016). Disaster Risk Profile Zanzibar. Washington, DC: Southwest Indian Ocean Risk Assessment and Financing Initiative.

Ufuzo, S. S. (2012). Participatory Mapping to Assess the Decline of Groundwater resources: The Case of Mtoni and Bububu-Mwanyanya Springs- Zanzibar. Unpublished Master Thesis: Enschede, The Netherlands.

UNDP. (1987). Hydrogeological Map of Zanzibar: Including the Islands of Zanzibar and Pemba, The United Republic of Tanzania. New York: United Nations.

URT. (2013). 2012 Population and Housing Census: Population Distribution by Administrative Areas. Dar es Salaam: The United Republic of Tanzania.

Ülker, D., Ergüven, O., Gazioğlu, C. (2018). Socioeconomic impacts in a Changing Climate: Case Study Syria. International Journal of Environment and Geoinformatics, 5(1), 84-93 doi.10. 30897/ijegeo.406273

Van Sickle, J. P. (2016). Modeling Spring Catchment Discharge: A Case Study of Candela, Panama Central America. Open Access Master's Report, Michigan Technological University. Retrieved from http://digitalcommons.mtu.edu/etdr/217.

Watkiss, P. P., Hendriksen, S., Maclean, G., Bonjean, A., Shaghude, M. Y., Jiddawi, N., Khamis, Z. (2012). The Economics of Climate Change in Zanzibar. Study Report for the Revolutionary Government of Zanzibar, Climate Change Committee.

Weissinger, R., Philippi, T. E., Thoma, D. (2016). Linking climate to changing discharge at springs in Arches National Park, Utah, USA. Ecosphere, 7(10), 1-12. doi:org/10.1002/ecs2.1491

ZAWA. (2009). Zanzibar Water Strategy for 2009-2015. Unpublished.

ZAWA. (2014). Consultancy Services for Design, Bid Documents Preparation and construction Supervision of Zanzibar Urban Water and Sanitation
Project: Water Sources Study Final Report. Zanzibar, Tanzania: Unpublished Report: Zanzibar Water Authority. 